DOI: 10.18468/letras.2017v7n1.p317-348

TRANSPOSIÇÃO DIDÁTICA E DIDATIZAÇÃO NO CAMPO DA

EDUCAÇÃO AMBIENTAL E OS MATERIAIS DIDÁTICOS IMPRESSOS

\author{
Rosivaldo Gomes ${ }^{1}$ \\ Adelma das Neves Nunes Barros Mendes ${ }^{2}$
}

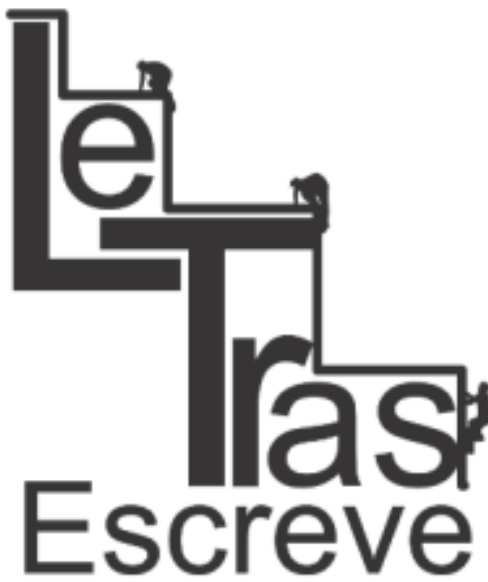

(ISSN 2238-8060)

RESUMO: Neste artigo apresentamos algumas reflexões sobre os processos de transposição didática e didatização em articulação com materiais didáticos voltados para Educação Ambiental. Para isso, discutimos a partir de Chevallad (1985) e Barros-Mendes (2005) os conceitos desses dois processos, bem como na Lei no 9.795/1999 que dispõe sobre a educação ambiental e que institui a Política Nacional de Educação Ambiental sobre a produção de materiais didáticos voltados para a educação ambiental. Discutimos, ainda, com base em Gomes e Barros-Mendes (2012) e em Mendonça (2010) algumas definições sobre o gênero discursivo cartilha quadrinizada e a constituição desse gênero a partir da visão enunciativo-discursiva de Bakhtin (2003). O estudo está situado no quadro teórico-metodológico da Linguística Aplicada transdisciplinar (MOITA-LOPES, 2006). Os resultados revelam que aos processos de transposição didática e didatização concretizam possiblidades de trabalhos no ensino a partir de temas ambientais, uma vez que as atividades analisadas a partir de uma cartilha de educação ambiental, apesar de trabalharem de forma simples, conduzem o leitor no caso em potencial a criança - no processo de transposição e didatização dos temas ambientais não apenas para reprodução de conhecimentos epistemológicos sobre problemas ambientais, mas favorecem acima de tudo reflexões maiores a respeitos deles, levando os alunos a uma visão mais holística e crítica sobre a educação ambiental.

Palavras-chave: Materiais Didáticos. Educação Ambiental. Transposição e didatização.

RÉSUMÉ: Cet article présente quelques réflexions sur le processus de transposition didactique et didactisation conjointement avec des matériaux éducatifs axés sur l'éducation environnementale. Pour cela, nous avons discuté des concepts Chevallad (1985) et Barros-Mendes (2005) de ces

\footnotetext{
${ }^{1}$ Graduado em Letras Português e Literatura pela Universidade Federal do Amapá e Mestre pelo Programa de Pós-Graduação em Direito Ambiental e Políticas Públicas (PPGDAPUNIFAP), com pesquisa voltada para a Análise Dialógica do Discurso (ADD). É doutorando em Linguística Aplicada - Instituto de Estudos da Linguagem da Universidade Estadual de Campinas/IEL-UNICAMP. Professor do Departamento de Letras, Arte e Comunicação da Universidade Federal do Amapá-UNIFAP.E-mail: rosivaldo@unifap.br

2 Possui graduação em Letras pela Universidade Federal do Amapá (UNIFAP, 1995), Mestrado em Linguística Aplicada pela UNICAMP (2001) e Doutorado em Linguística Aplicada e Estudos da Linguagem pela PUC de São Paulo (2005) com estágio de Doutorado na Universidade de Genebra/Suíça. Atualmente é professora Associada 1 da UNIFAP. E-mail: adelma@unifap.br
}

https://periodicos.unifap.br/index.php/letras

Macapá, v. 7, n. I, Io semestre, 2017. 


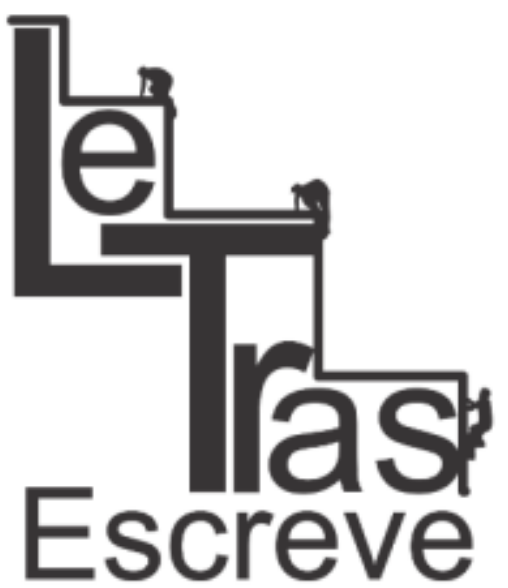

(ISSN 2238-8060)

deux processus, ainsi que dans la loi $n^{\circ} 9.795$ / 1999 qui prévoit l'éducation environnementale et d'établir la politique nationale de l'éducation environnementale sur la production matériel pédagogique liés à l'éducation environnementale. Nous discutons également, sur la base Gomes et Mendes-Barros (2012) et Mendonça (2010) quelques définitions du discours sur le genre amorce quadrinizada et la constitution de ce genre de la vision énonciatif-discursive de Bakhtine (2003). L'étude est dans le cadre théorique et méthodologique de transdisciplinaires linguistique appliquée (MOITA-LOPES, 2006). Les résultats montrent que le processus de transposition didactique et didactisation matérialisent les possibilités de travail dans l'enseignement des questions environnementales, puisque les activités analysées à partir d'un livret d'éducation environnementale, bien que travaillant dans un simple conduit le lecteur - dans si l'enfant potentiel - dans le processus de transposition et didactisation des questions environnementales, non seulement pour jouer la connaissance épistémologique des problèmes environnementaux, mais surtout grâce réflexion à les respecter, ce qui conduit les étudiants à une vision plus globale et critique sur l'éducation l'environnement.

Mots-clés: Matériel pédagogique. Éducation à l'environnement. Transposition et didactisation.

\section{Considerações iniciais}

O que torna um material didático?

Qualquer instrumento que utilizemos para fins de ensino/aprendizagem é um material didático. A caneta que o professor aponta para os alunos, para exemplificar o que seria um referente possível para a palavra caneta, funciona, nessa hora, como material didático. Assim como o globo terrestre, em que a professora de Geografia indica, circulando com o dedo, a localização exata da Nova Guiné. Ou a prancha em tamanho gigante que, pendurada na parede da sala, mostra de que órgãos o aparelho digestivo se compõe, o que, por sua vez, está explicado em detalhes no livro de Ciências. A diferença entre cada um desses recursos é apenas o grau de especialização: a caneta não foi criada para servir de exemplo para a noção de referente, mas, em graus crescentes de especialização e intencionalidade didáticas, o globo, a prancha e o livro, sim. (RANGEL, 2005, p. 25).

A citação acima, que serve como epígrafe para a abertura deste artigo, possibilita-nos a reflexão sobre o papel desempenhado pe-

https://periodicos.unifap.br/index.php/letras

Macapá, v. 7, n. I, Io semestre, 2017. 


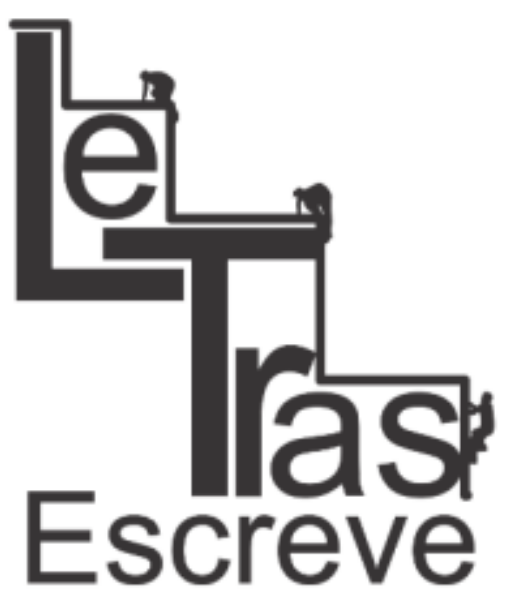

(ISSN 2238-8060)

los materiais didáticos no contexto do letramento escolar (BUNZEN, 2010; KLEIMAN, 2010) e os modos como esses são utilizados pelo professor. Como assevera Rangel (2005), no contexto de sala de aula, o professor mobiliza seus saberes sejam eles de sua formação profissional, disciplinares, curriculares ou experienciais (TARDIF, 2004) para fazer valer suas explicações sobre determinado conteúdo/saber/conhecimento, apoiando-se, portanto, em diversas estratégias didáticas e materiais. No campo da educação ambiental ${ }^{3}$, não muito diferente dos demais, os professores em suas diferentes disciplinas têm buscado, a partir de diversas atividades, projetos temáticos, feiras, textos, etc., "presentificar" a educação ambiental em suas aulas, pois como salienta Reigota (2004, p.25)

a educação ambiental, como perspectiva educativa, pode estar presente em todas as disciplinas, quando analisa temas que permitem enfocar as relações entre a humanidade e o meio natural, e as relações sociais, sem deixar de lado as suas especificidades.

Essa legitimação, tal como propõe Reigota (2004), da presença da educação ambiental, bem como de temas relacionados a ela, adentram na escola por diversas fontes como, por exemplo, vídeos, textos apresentados pelos professores ou presentes nos livros didáticos e, também, por meio de materiais didáticos impressos instituídos por órgãos públicos e privados, sendo que nesses materiais subjazem concepções de educação ambiental que auxiliam na construção de letramentos críticos $^{4}$ por parte dos alunos a respeito de questões socioambientais e sobre sustentabilidade.

Para Chevallard (1985), essa entrada (seleção do que entra, de

\footnotetext{
${ }^{3}$ Compreendemos campo no sentido de área de conhecimento ou saberes.

${ }^{4}$ Conforme assevera Monte Mór (2013b, p.42) "o[s] letramento[s] crítico[s] parte[m] da premissa de que a linguagem tem natureza política em função das relações de poder nela presentes".
}

https://periodicos.unifap.br/index.php/letras

Macapá, v. 7, n. I, Io semestre, 2017. 


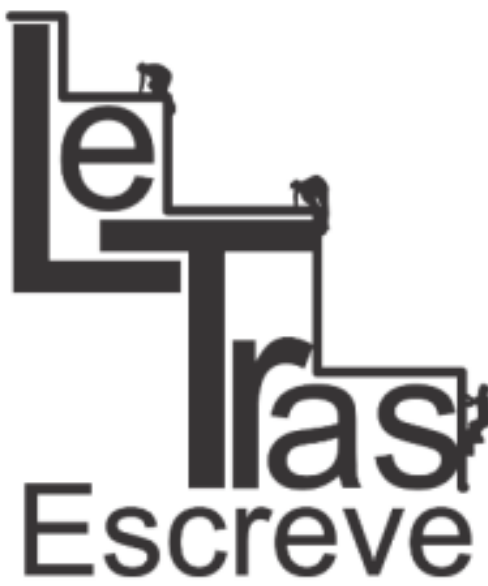

(ISSN 2238-8060)

que esferas, que tipos de suportes, textos e materiais) se faz por meio da Noosfera, ou seja, uma esfera "invisível" responsável, nesse caso, pela transposição didática de saberes sobre a educação ambiental, sendo que a organização desses saberes (o que ensinar e como ensinar) fica a cargo da didatização (BARROS-MENDES, 2005).

Considerando essas questões, este artigo apresenta algumas reflexões presentes na dissertação de mestrado defendida em 2013 ${ }^{5}$, no Programa de Pós-Graduação de Mestrado de Direito Ambiental e Políticas Públicas da Universidade Federal do Amapá (PPGDAPUNIFAP). Para este estudo, objetivamos analisar e discutir como temas sobre educação ambiental são transpostos e didatizados em Cartilhas Quadrinizadas de Educação Ambiental (CQEA), bem como examinar, a partir de recursos semióticos, como o saber científico sobre educação ambiental é didatizado nas CQEA.

Para isso, levamos em conta as noções de Chevallad (1985) e Barros-Mendes (2005) a respeito dos conceitos de transposição didática e didatização e também o que propõe a Lei no 9.795/1999 que trata sobre orientações a respeito da produção de materiais didáticos no campo de educação ambiental. Discutimos, ainda, com base em Gomes e Barros-Mendes (2012) e em Mendonça (2010) algumas definições sobre o gênero discursivo cartilha quadrinizada e a constituição desse a partir da visão enunciativo-discursiva de Bakhtin (2003).

O estudo está situado no campo da Linguística Aplicada transdisciplinar/indisciplinar (MOITA-LOPES, 2006), que possibilita a mobilização de apostes teórico-metodológicos que objetivam tratar de questões e problemas de relevância social suficiente para exigirem

\footnotetext{
${ }^{5}$ Dissertação intitulada, O Discurso sobre Educação Ambiental em Cartilhas quadrinizadas: uma análise a partir da abordagem dialógica do discurso, foi orientada pela profa. Dra. Adelma Barros-Mendes, tendo sido financiada, no primeiro ano de realização do curso, com apoio de bolsas pela Coordenação de Aperfeiçoamento de Pessoal de Nível Superior - CAPES
}

https://periodicos.unifap.br/index.php/letras

Macapá, v. 7, n. I, Io semestre, 2017. 


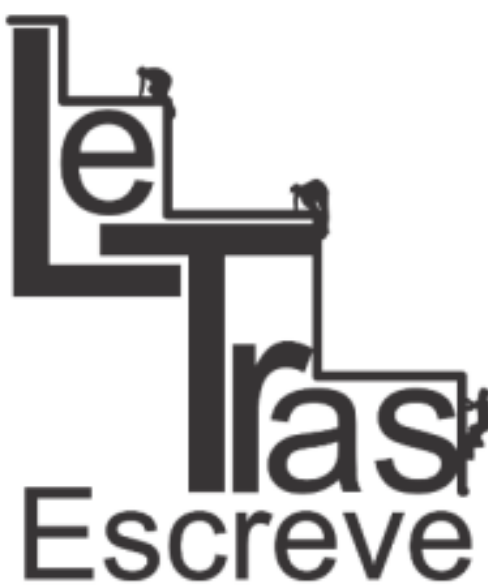

(ISSN 2238-8060)

respostas teóricas que tragam ganhos a práticas sociais e a seus participantes, no sentido de uma melhor qualidade de vida, num sentido ecológico, tal como defendido por Rojo (2006).

Assim, o artigo está organizado da seguinte forma: primeiramente, realizamos uma discussão sobre os conceitos de transposição didática e didatização, mostrando possíveis relações entre esses conceitos e os temas do campo da educação ambiental; em seguida, discorremos acerca da educação ambiental e os materiais didáticos, situando discussões tanto teóricas quanto de base legais. Passamos, em seguida, para apresentação, a partir da visão bakhtiniana, do gênero cartilha quadrinizada e, posteriormente, para a análise dos dados. Por fim tercemos algumas considerações sobre o trabalho como um todo.

\section{Transposição didática e os temas ambientais}

Não muito diferente dos demais saberes, quando se discute a questão ambiental, como um saber a ser ensinado na escola pela via da educação ambiental formal, é possível entendermos que esse saber não entra na escola e nem passa a ser figurado nos matérias didáticos como um saber científico, mas como um saber que precisa sofrer transformações e não simplificações e, além disso, "é necessário que sejam coerentes e estejam sustentados por fundamentos epistemológicos claros" (BARROS-MENDES, 2005, p.18), ou seja, um saber a ser ensinado e, a partir da didatização, um saber aprendido pelo aluno.

Sobre essa transformação de saberes, o sociólogo Michel Verret, em 1975, na França, cunha o termo Transposição didática (TD, doravante), porém conforme aponta Teixeira (2011) poucos anos depois - em 1980 -, o didata das matemáticas Yves Chevallard revisita 


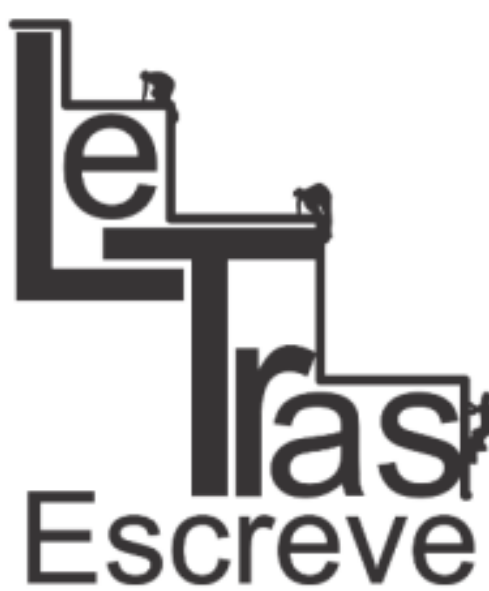

(ISSN 2238-8060) as propostas teóricas de Michel Verret a respeito desse conceito e as adapta a outro contexto, defendendo a ideia de que é preciso haver certa distância entre os saberes científicos e os saberes escolares. Yves Chevallard e Marie-Alberte Joshua, utilizaram, então, o termo TD para analisar e discutir as transformações sofridas com a noção matemática de distância entre o momento de sua introdução em 1906, por Fréchet, no "saber de referência" e o momento de sua introdução em 1971 nos programas de geometria da sétima série, em relação com a reta. Ou seja, eles analisavam a transformação do conhecimento matemático dos cientistas até a sua adequação às salas de aulas pelos professores, de uma maneira que os alunos pudessem compreender esse conhecimento.

Nessa esteira, a TD pressupõe a existência de um processo, e que um conteúdo do conhecimento, tendo sido designado como saber a ser ensinado sofre, a partir daí, um conjunto de transformações adaptativas que o levam a tomar lugar entre os objetos de ensino. Assim, a TD é o percurso de transformações ocorridas no saber de referência até se tornar um saber da sala de aula, passando, portanto, fases (CHEVALLARD, 1985) como apresentado na Figura 1:

Figura 1: Processo de Transposição didática 1) CONHECIMENTO CIENTIFICO SOBRE DETERMINADO SABBER

A) construçăo do conceito científico

\section{2) CONHECIMENTO A SER ENSINADO}

B) a entrada do saber clentifico no curriculo caracterizando o saber como objeto de ensino

3) CONHECIMENTO SOERE O SABER EFETIVAMENTE ENSINADO

c) a retrataçjo do saber nos fivros didáticos, materiais paradidaticos e/ou dispostivos e os modos de testualizacto escolar do saber cientifico.

3) CONHECIMENTO SOBRE O SABER EFETIVAMENTE APRENDIDO

D) do saber de ensino, caractetizado como objeto de ensino, ate a sue assimilaçăo pelo estudante

Fonte: Chevallard (1985). 
Contudo, a transformação do saber para sala de aula tem sido interpretada como uma mera simplificação do conhecimento, de modo a se adequar melhor na sala de aula, sendo necessário que se discuta mais sobre tal processo, pois como destaca Pinho Alves (2001)

a primeira vista somos levados a interpretar que o saber a ensinar é apenas uma mera simplificação ou trivialização formal dos objetos complexos que compõe o repertório do saber de referência. Esta interpretação é equivocada e geradora de interpretações ambíguas nas relações escolares, pois revela o desconhecimento de um processo complexo do saber. (p.225).

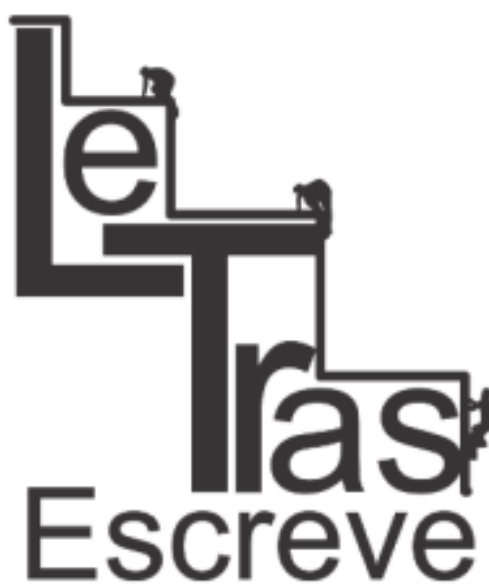

(ISSN 2238-8060)

(1)

luno na e para a compreensão do funcionamento desse saber que é socialmente legitimado.

Nessa mesma direção, Barros-Mendes (2005) defende que a transposição didática dos saberes científicos não pode ser feita de forma direta e imediata ao contexto escolar, o que significa dizer que os saberes ensinados não podem ser simples "adaptações" ou "decalques" das teorias elaboradas por pesquisadores ou experts, já que não se objetiva forma especialistas nesta ou naquela área, mas sim alunos capazes de refletirem criticamente sobre o que aprenderam/aprendem/aprenderão.

Assim, na transformação sofrida pelo saber de referência, é levada em conta uma série de fatores que influenciam no aprendizado desse novo conteúdo, isto é, adéqua-se o saber em sua sequência 
(que na maioria das vezes é anacrônica), em sua linguagem, em exercícios, problemas e atividades, objetivando sempre a catalisação do aprendizado. Essa transformação torna-se necessária já que aos saberes de referência são incorporadas novas funções e sendo necessária, portanto, adequação à realidade da sala de aula, como propõe Schneuwly (1995a)

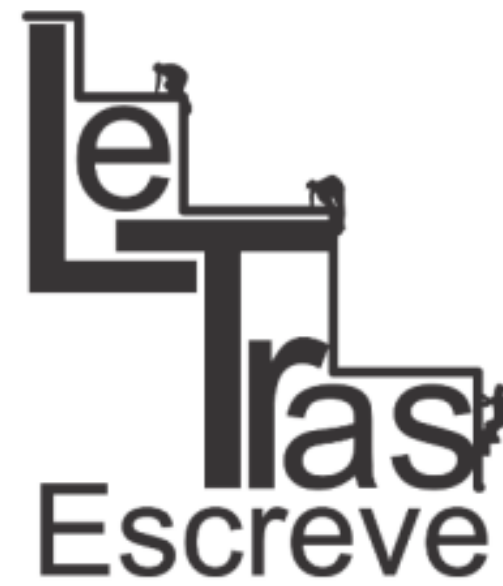

(ISSN 2238-8060) este movimento de tirar o objeto de seu contexto para ser colocado dentro de outro para ser ensinado, transforma fundamentalmente o sentido deste objeto. Por exemplo, o fato de se tomar um gênero de discurso e colocá-lo em contexto escolar, faz com que este gênero não tenha mais a mesma função, ele se transformou em um objeto de ensino. Para os alunos, subsistem os traços de seu funcionamento anterior [...]. Não se pode ensinar sem que se faça a transposição (SCHNEUWLY, 1995, p.1415).

Nesse processo, há a existência de três níveis ou patamares do saber: o saber de referência, de onde se inicia o processo; o saber $\boldsymbol{a}$ ensinar e o saber ensinado, cada um com sua própria comunidade autônoma, com seus representantes ou grupos. No processo de constituição desses níveis tem-se a Noosfera, que se constitui numa esfera de ação, na qual os protagonistas atuam na transformação do saber. Essa esfera acaba envolvendo pessoas e/ou instituições que influenciam o sistema educacional, ou seja, todo personagem ou instituição social, econômica e política que influencia nas transformações sofridas pelo saber é considerado parte da noosfera, sendo que nela ocorrem conflitos inevitáveis e as transformações dos saberes, pois os vários atores das diferentes esferas sociais negociam seus interesses e pontos de vistas.

Nesse sentido, como assevera Chevallard (1985, p. 28) 
na noosfera (...) os representantes do sistema de ensino, com ou sem mandatos (desde o presidente de uma associação de professores até um simples professor militante), se encontram, direta ou indiretamente, (...), com os representantes da sociedade (os pais dos alunos, os especialistas das disciplinas que militam em torno de seus ensinos, os emissários de órgãos políticos).

A noosfera envolve, portanto, o sistema didático, tornando-se a dimensão onde são discutidos os problemas e debatidas as soluções pelos representantes principais do sistema didático, responsáveis, nesse caso, pelo "bom" funcionamento dele. Ela envolve, como dissemos anteriormente, todos os representantes do sistema de ensino, como os autores de livros didáticos, as políticas educacionais, pesquisadores em ensino, professores e até os representantes da sociedade, como por exemplo, os pais de alunos, especialistas das disciplinas e outros interessados no processo de ensino.

\subsection{Os níveis do saber}

A Noosfera é a responsável pelo fio condutor da transposição didática que envolve também os níveis do saber, sendo eles de três tipos: O saber de referência, o saber a ensinar e o saber ensinado. 0 Saber de Referência diz respeito ao saber inicial, aquele saber que é tomado como base na definição da disciplina escolar. Tal saber é, em geral, aquele construído no interior da comunidade científica (mas não o único). Esse saber também passa por transformações no interior dessa comunidade até tornar-se público, quando da publicação em revistas específicas das comunidades científicas como, por exemplo, os artigos publicados em revistas especializadas em temas ambientais, sendo objeto de debates, revisões e controvérsias. Antes da pu- 


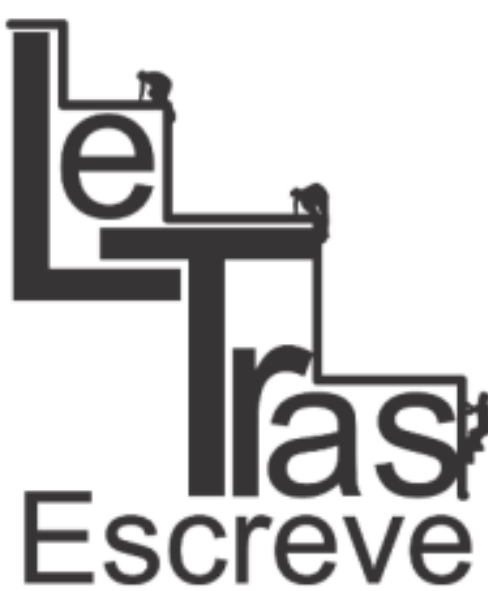

(ISSN 2238-8060)

blicação é possível acessar o processo de construção específica da área científica em questão.

Dessa forma, ao ser publicado, o conhecimento está "limpo", "depurado" e em uma linguagem que nem sempre retrata características de sua construção. Esse patamar do saber é composto por pessoas responsáveis pela sua construção e desenvolvimento no interior das comunidades de pesquisas, isto é, os cientistas e pesquisadores de uma maneira geral. A construção desse novo saber pelo cientista, normalmente, se inicia com a busca por uma resposta ou solução de algum problema. Nessa busca, o cientista acaba por percorrer caminhos em seus raciocínios que não são descritos em seus artigos, devido ao grau de informalidade que o levou a fazer a descoberta.

Nessa perspectiva, Chevallard (1985) explica que esse processo é denominado "contexto da descoberta", se referindo a uma etapa pessoal do cientista, onde ele busca a sua resposta. Porém, para formalizar sua solução, ele tem que abrir mão da informalidade, fazendo análises e apreciações valorativas da solução encontrada. Somente assim, seu trabalho ou artigo poderá ser publicado, pois desta forma, ele estará adequando seu trabalho às normas impostas pela comunidade científica através de linguagem e regras peculiares dessa comunidade. Esse processo é denominado "contexto da justificativa".

Esse processo de transformar o saber de referência em saber a ensinar corresponde a TD externa. Ele se materializa na produção de livros didáticos, manuais de ensino para formação universitária, programas escolares que têm como alvo os alunos universitários e professores da Educação Básica. Nesses casos, o conhecimento é reestruturado para uma linguagem mais adequada ao ensino, sendo "desmontado" e reorganizado novamente de uma maneira lógica e atemporal. 
Os autores de livros didáticos, materiais didáticos, os especialistas das disciplinas, os professores, a opinião pública em geral, por meio do poder político que influencia de alguma maneira na transformação do saber, são exemplos dos atores desse patamar do saber. É esse grupo que vai determinar quais as transformações e o que deverá ser transformado do saber de referência em saber a ensinar, gerando um novo saber que estará mais próximo da escola.

Nesse processo, ao ser transformado em saber a ensinar, o saber de referência sofre uma descontextualização, ocorrendo a perda do seu contexto original, através de um processo que Chevallard (1985) denomina de despersonalização. O saber de referência passa por uma espécie de elementarização para que depois volte a ser reconstruído, permitindo uma nova estruturação e organização. Assim, esse saber passa a ter uma configuração dogmática, ordenada, cumulativa e de certa maneira linearizada, tornando-se um saber com uma sequência lógica, passando a ter um novo contexto.

Há ainda o saber ensinado, isto é, a segunda transposição do saber, que transforma o saber de acordo com tempo didático, ou seja, é nessa etapa que há transformação do saber visando ao sequen(ISSN 2238-8060) ciamento das aulas. Esse processo de transformação do saber a ensinar em saber ensinado é denominado "transposição didática interna", pois ocorre no interior do espaço escolar.

Nesse papel de transformação do saber para sala de aula, aparece a figura do professor, que deve adequar o saber trazido nos manuais de ensino (saber a ensinar) para aquele que efetivamente vai para suas aulas e chegue até os alunos. O professor é o principal ator dessa transposição, desempenhando papel central nesse nível do saber. Porém, não é o único, os alunos e a administração escolar (diretor, orientadores, pedagogos, etc.) também são os representantes 
desse patamar na noosfera.

Compreendemos que esse é o saber que de fato chega ao aluno, depois de sofrer dois recortes. Nessa segunda transformação, o professor acaba sofrendo interferências de outros membros da noosfera, devido à interação que ocorre entre eles, isso faz com que outros interesses, além dos seus, sejam levados em consideração no processo.

Nesse contexto, forma-se um novo ambiente epistemológico, porém muito mais instável, se comparado com o do saber de referência e do saber a ensinar, já que "cada nova transposição cria um quadro epistemológico novo [...] dentro de cada quadro novo, é feito o possível para reduzir as dificuldades de aprendizagem, dissolvê-

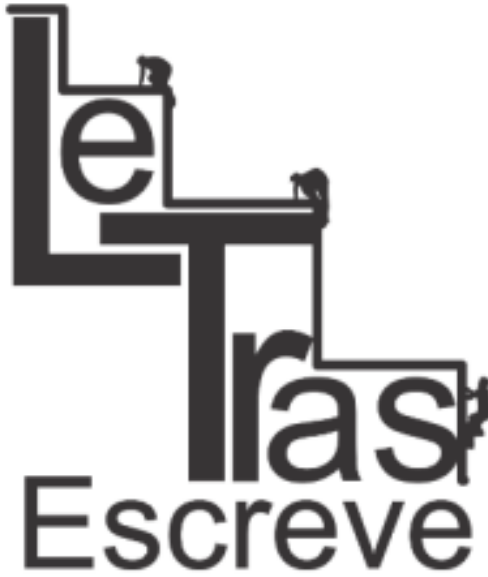

(ISSN 2238-8060) las", como afirma Chevallard (1985, p. 81). Assim, na Figura 2, segue o percurso descrito, até agora, da evolução dos saberes:

Figura 2: Representação da evolução dos saberes proposta por Yves Chevallard

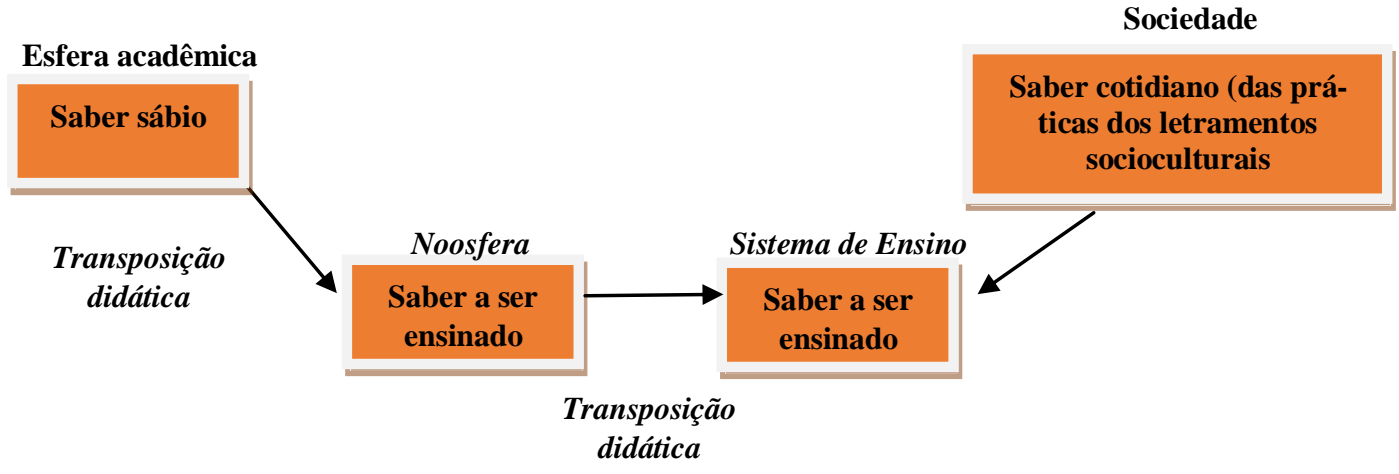

Fonte: Elaborado por Gomes (2012).

A partir do esquema apresentado na Figura 2, podemos então concluir que, como ferramenta de análise, a transposição didática consegue refazer os caminhos percorridos pelo saber, desde sua origem (Saber de Referência) até chegar a sala de aula (Saber Ensinado), deixando para noosfera o papel da seleção de quais serão os saberes 


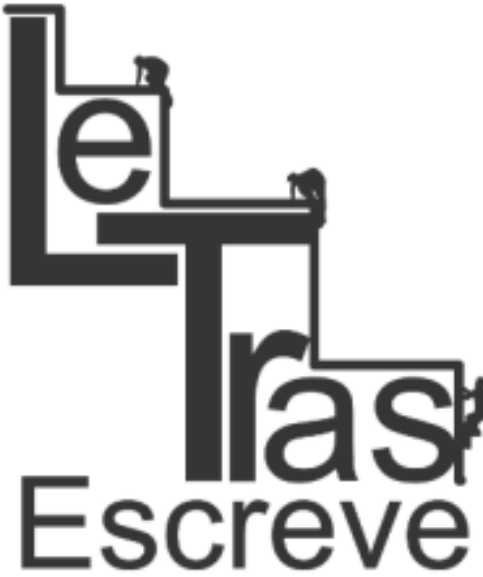

(ISSN 2238-8060)

de referência que passarão pelas transformações para chegar à sala de aula, porém, para chegar ao professor, o saber tem antes que sobreviver no nível do Saber a Ensinar.

Assim, a TD deve ter como referência várias fontes de saberes, sendo essas referências expressas em documentos oficiais - propostas curriculares municipais e estaduais, parâmetros curriculares nacionais e outros documentos são alguns exemplos dessas fontes. Esses saberes, tal como os saberes advindos da construção da ciência não podem ser transpostos diretamente para a sala de aula.

Além do mais, a transposição direta de documentos parametrizadores para a sala de aula é impossível, pois estes supõem diferentes níveis de concretização - entre outros, a própria elaboração de um projeto educacional de escola -, e seria, também indesejável, na medida em que isso desconsideraria características específicas de cada comunidade escolar. Além disso, é preciso que se leve em conta a situação e a esfera na qual se dá a construção do saber escolar, sem o que toda situação pedagógica fica comprometida.

Reconhecer essas situações implica pensamos também como a escola trabalha com os saberes culturalmente produzidos que, ao serem didatizados, tornam-se saberes escolares. Como já dito anteriormente, os saberes tratados na esfera escolar não são os mesmos da esfera científica nos quais se baseiam, mas também não são totalmente distintos, portanto, os saberes da cultura transformam-se em objeto de ensino e de aprendizagem escolar quando considerados no planejamento escolar.

Nesse sentido, há várias maneiras de se pensar a transformação dos saberes, sendo que uma delas consiste em se pensar que TD implica como uma simplificação dos objetos das ciências para que esses possam ser compreendidos pelos alunos. Todavia, se vermos

https://periodicos.unifap.br/index.php/letras

Macapá, v. 7, n. I, Io semestre, 2017. 


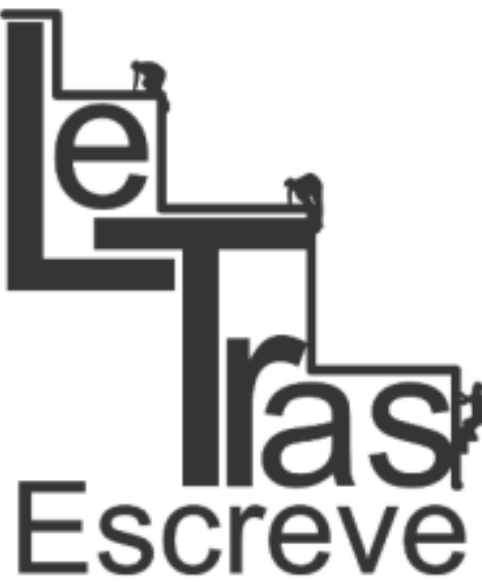

(ISSN 2238-8060)

apenas por esse ângulo, estaremos caindo no que já alerta BarrosMendes (2005) ao destacar que a essa transformação não pode ser vista/entendida como mera simplificação dos saberes. Tratar-se-ia, então, de adaptar, de facilitar, de desenvolver uma sistematização consistente sobre os saberes. Contudo, temos visto que longe dessa visão, a escola tem exercido um papel eminentemente reprodutor e preparador de ensino de conteúdos.

Em oposição a isso, pode-se pensar que a escola não só "importa saberes", (ROJO, 2004), mas também os produz, inclusive quando os "importa". Produz saberes didáticos, saberes corolários das ciências etc., não podendo ser compreendida, também, apenas como uma espécie de subesfera ou pré-esfera, que prepara os alunos para a vida em outras esferas (nomeadamente, a científica e do trabalho). Prova maior disso é que a escola, tal e qual todas as outras esferas, "produz" saberes específicos - os gêneros escolares são exemplos ilustrativos a esse respeito. Além disso, a escola também tem como objetivo a construção de capacidades, o que transcende ao ensino de conteúdos no sentido estrito do termo. No caso, por exemplo, de se definir como objeto de ensino para temas correlatos à educação ambiental.

\section{A didatização e seu papel no ensino dos temas ambientais}

Feitas as considerações sobre a TD, passamos, então, à discussão sobre didatização, que corresponde a um processo existente dentro da TD. Assim, selecionados pelos entendes da noosfera, os saberes precisam além de transpostos para o contexto de sala de aula, serem, conforme defende Barros-Mendes (2005, p.21) transformados em objetos de ensino, pois

https://periodicos.unifap.br/index.php/letras

Macapá, v. 7, n. I, Io semestre, 2017. 
transformados em saberes a serem ensinados, os saberes precisarão também ser didatizados e, embora fortemente relacionados entre si, os processos de transposição didática e de didatização não são sinônimos. Enquanto o processo de transposição se ocupa da transformação dos saberes de referência em saberes a serem ensinados, a didatização seria a maneira de organizar esses saberes para a compreensão do aluno. De maneira simplificada, poderíamos dizer que a didatização é o "como", por meio de exercícios e atividades, os saberes são expostos com a finalidade de concretizá-los em saberes ensinados e aprendidos.

Em direção semelhante a Barros-Mendes, Bezerra (2008) também propõe que a didatização não é um processo que equivale a TD, como muitos pensam. Ao contrário, eles são processos que se diferenciam, apesar da interligação que há entre eles. Para essa autora, a didatização como conceito oriundo dos estudos sobre didática de tradição francófona, configura-se como um processo do ensino de determinado conteúdo, que, após passar pela TD, é caracterizado como objetivo de ensino a partir de determinada metodologia, isto é, "a didatização corresponde/remete as reformulações, ou seja, aos modos de ensinar em sala de aula". (BEZERRA, p.135).

Nesse sentido, a didatização exerce papel fundamental no processo de transformações dos conhecimentos, uma vez que sem esse processo o saber a ser ensinado, no espaço escolar, acaba seguindo o caráter científico do saber. Além dessa questão, vale destacar que, no processo de didatização, está implicada a questão da sistematização desses saberes, já que

tal sistematização não estaria necessariamente vinculada a uma ordem, um "passo a passo" ou ao relevo dados a esses saberes, mas sim a uma "organização do todo" que componha cada objeto, de forma que os saberes referentes a esses objetos pos-

https://periodicos.unifap.br/index.php/letras

Macapá, v. 7, n. I, Io semestre, 2017. 
sam vir a ser apreendidos e aprendidos de fato, mas considerando a dinâmica de cada sujeito aprendiz. (BARROS-MENDES, 2005, p. 22).

Com essas descrições, podemos entender, portanto, a didatização como um processo existente dentro da TD, que envolve transformações de conhecimentos para se adequar ao nível dos aprendizes, requerendo, assim, planejamento e construção de modelos didáticos para a efetivação da aprendizagem dos objetos ensino aos níveis dos alunos. A didatização, portanto, está relacionada estritamente com o agir, fazer ou gestos didáticos do professor no tratamento com os objetos de ensino.

\section{A educação ambiental e os materiais didáticos}

A educação ambiental, em sentido amplo, vem se disseminando no ambiente escolar brasileiro já há alguns anos, sendo que essa institucionalização tem pressionado escolas a desenvolverem diversas ações, tais como projetos de educação ambiental, que objetivam envolver todo o corpo pedagógico, mas principalmente os professo-

(ISSN 2238-8060) res e alunos. Nesse contexto, a educação ambiental já é uma realidade nas práticas do letramento escolar como destaca Guimarães (2004), tanto para os professores quanto para alunos, sendo que esses docentes estão fazendo ou se sentem compelidos a inserirem, em suas disciplinas, questões relativas à educação ambiental.

Guimaraes (2004) destaca, ainda, que apesar dessa realidade está fortemente presente nas escolas brasileiras, ainda há fragilidade sobre essa temática, uma vez que

a ação educativa reconhecida como educação ambiental geralmente se apresenta fragilizada em sua 
prática pedagógica. Fragilizada por considerar que a superação da crise ambiental passa pelo processo de profundas transformações socioambiental e que, para contribuir nesse processo, a EA precisa assumir o caráter crítico-transformador. (GUIMARÃES, 2004, p. 119-120).

Nesse viés, os professores, na maior parte das vezes, estão preocupados com a degradação da natureza, escassez dos recursos naturais, etc., e no processo de transposição didática desses temas acabam enfatizando apenas uma visão de educação ambiental, deixando muitas vezes de lado o processo de didatização que esses temas merecem e mesmo se mobilizando com empenho sincero para enfrentar essas questões, as práticas resultantes, geralmente, são

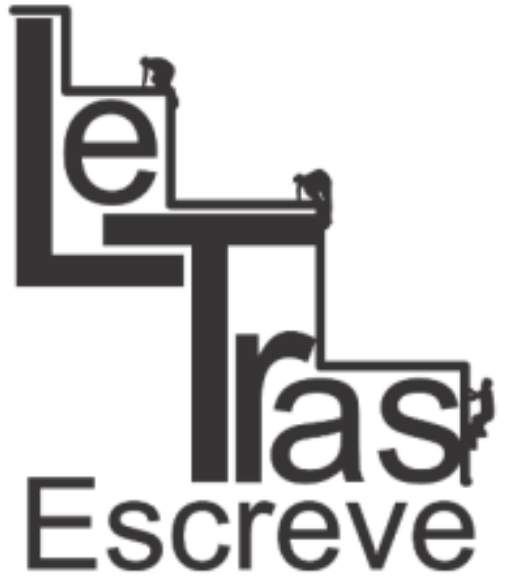

(ISSN 2238-8060)

pouco eficazes para atuar de forma significativa no processo de transformação da realidade ambiental, até mesmo dentro da própria escola onde atuam.

Ao mesmo tempo em que essa realidade escolar tem sido evidente cada vez mais forte, outra também se impõe, pois, para Guimarães (2004)

É interessante notar como a preocupação ambiental e, particularmente, as práticas de educação ambiental vêm se constituindo com um bem na contemporaneidade. Isto é, um sentido valorizado pela sociedade que tende a ser incorporado pela educação, ao mesmo tempo em que se oferece como ideal para os processos de formação identitária. (p.32).

Nessa direção, podemos dizer que a formação em educação ambiental passa, então, ser não apenas uma prática intrinsecamente educacional, pois também tem agregado crenças, valores, atitudes e práticas sociais orientadas e que de certa forma convertem-se num valor ao mesmo tempo social e pessoal. Vale ainda destacar que, no

https://periodicos.unifap.br/index.php/letras

Macapá, v. 7, n. I, Io semestre, 2017. 


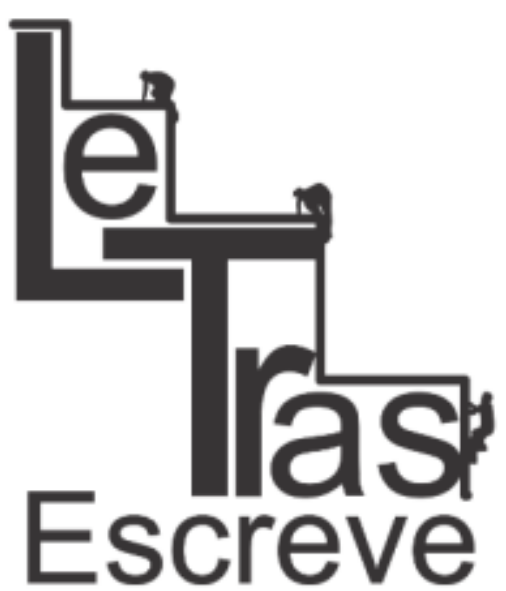

(ISSN 2238-8060)

horizonte da modernidade, como destaca Latour (1994), tornou-se impossível assegurar uma ideia de bem viver. A educação ambiental e a formação nessa área poderiam ser pensadas como portadoras de um ideal ético - que entende o ambiente como um bem - e educação ambiental tem sido apontada como um dos campos de transformação da sociedade contemporânea ou como esperança de pandora como afirmam Santos e Sato (2001).

Mas por que os professores não conseguem ir além de uma proposta de educação ambiental conservadora, mesmo quando sensibilizados e motivados a inserir a dimensão ambiental em suas práticas educativas? Carvalho (2004, p.40) ajuda-nos a pensar nessas questões ao salientar que

os percursos e trajetórias profissionais de educadores ambientais demarcam uma experiência escolar, mas principalmente social que torna possível falar de um campo ambiental. As estratégias, as posições, as lutas, as composições de formas desse campo podem, portanto, ser reconstruídas e tematizadas pela via dos relatos autobiográficos centrados nas trajetórias do que se poderia chamar "profissionais ambientais". E, além disso, esse campo ambiental apresenta a eles materiais didáticos sobre temas ambientais que ora se aproximam de aspectos técnico ora de aspectos didatizados.

Podemos então compreender, a partir do que defende CarvaIho (2005), que esses profissionais participam dinamicamente de um campo social particular - ao mesmo tempo em que o constituem estando, dessa maneira, sujeitos às regras de funcionamento desse campo. Levando em consideração o conceito de campo defendido por Bourdieu (1996) esses formadores ambientais compartilham de um habitus e estão sujeitos aos efeitos desse campo. Em outras palavras, no caso do campo ambiental, trata-se de descrever uma série

https://periodicos.unifap.br/index.php/letras

Macapá, v. 7, n. I, Io semestre, 2017. 


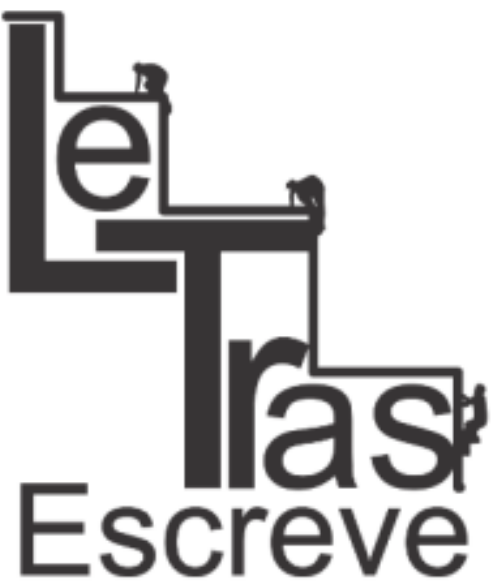

(ISSN 2238-8060)

de posições ocupadas nele pelo mesmo agente - no caso os formadores ambientais -, como por exemplo: as experiências que marcam seu ingresso no campo (militância, ativismo, atuação profissional, adesão aos tipos de práticas e discursos de educação ambiental, entre outras); papeis que desempenham e lugares que ocupa.

Tal situação pode ser evidenciada, também, quando um educador ambiental ao ser entrevistado responde sobre o início de seu trabalho dizendo ter sido não exatamente por uma razão nobre, mas por interesse em participar de algum trabalho interessante numa organização ou em sua escola. Esse discurso dialoga, como defende Bakhtin (2003) com outros discursos pertencentes a este campo/esfera discursiva, ou seja, com um ideal de militância, um dos sentidos recorrentes nesse campo ambiental.

A partir dessa visão, percebemos que, se comparado com outros campos mais consolidados na sociedade, como por exemplo, o campo político, campo literário, campo artístico, etc. o campo ambiental pode ser considerado como um campo recente, emergente, pois como defende Carvalho (2005):

\begin{abstract}
O fenômeno ambiental vem se estruturando, recentemente, na forma de um campo social, desde que passou a ocupar o espaço público de forma significativa na história recente. Despertando pelas mãos do movimento social contracultural nos anos 60/70, tomando como objeto de institucionalizações científicas e de governo, o campo ambiental, portanto, vem institucionalizando-se e gerando diferentes espaços e atores socais de diversas naturezas. (p.4243).
\end{abstract}

Esses diferentes espaços e atores sociais, mencionados pela autora, podem ser compreendidos como sendo os movimentos sociais de diferentes perfis ideológicos, partidários, agências governa-

https://periodicos.unifap.br/index.php/letras

Macapá, v. 7, n. I, Io semestre, 2017. 
mentais e intergovernamentais, políticas públicas que estão envolvidas direta ou indiretamente com o campo ambiental. Assim, esse campo tem se constituído um espaço próprio nas estruturas de ensino, tanto por meio dos cursos destinados à formação de profissionais ambientais, passando por políticas públicas de educação ambiental, quanto o fazer da sala de aula e a elaboração de materiais didáticos com temas voltados para a educação ambiental.

No que diz respeito à produção de materiais que envolvem temas ambientais, vale destacar o que propõe Lei $n^{\circ} 9.795$, de 27 de abril de 1999, que dispõe sobre a educação ambiental e institucionalização da Política Nacional de Educação Ambiental

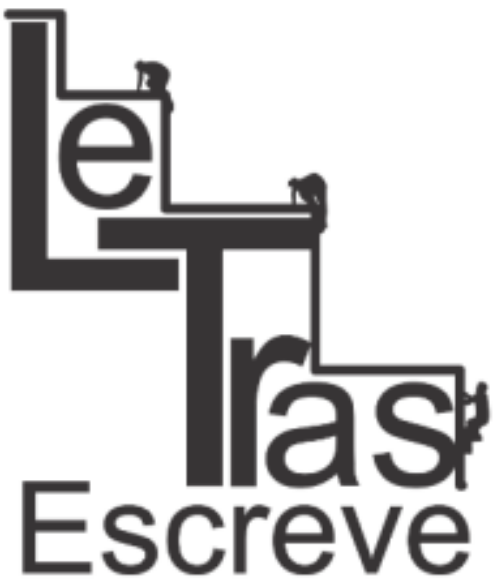

(ISSN 2238-8060)

Art. $8^{\circ}$ As atividades vinculadas à Política Nacional de Educação Ambiental devem ser desenvolvidas na educação em geral e na educação escolar, por meio das seguintes linhas de atuação inter-relacionadas:

I - capacitação de recursos humanos;

II - desenvolvimento de estudos, pesquisas e experimentações; III - produção e divulgação de material educativo ${ }^{30}$;

IV - acompanhamento e avaliação. (BRASIL, 1999, p. $1)$.

Nesse contexto da década de 90 do século passado, a legislação brasileira já chamava atenção para elaboração de materiais didáticos voltados para as discussões sobre a educação ambiental, porém esta preocupação, segundo Dendena (2008) fica mais evidente, no Brasil, a partir do início dos anos 2000, quando esses materiais didáticos sobre educação ambiental ou que envolvem temas correlatos à temática ambiental, como sustentabilidade, meio ambiente, etc. ganham maior evidência ao divulgarem assuntos, como, por exemplo,

https://periodicos.unifap.br/index.php/letras

Macapá, v. 7, n. I, Io semestre, 2017. 
danos ambientais e despejo de resíduos sólidos, pois

atualmente vemos um "bombardeio" de informações sobre poluição e preservação do meio ambiente, formas de "amenizar" as consequências do aquecimento global, efeito estufa, entre outras. Todas estas notícias veiculadas pelos meios de comunicação de massa, dos quais o mais utilizado é a televisão, os jornais, revistas, revistas em quadrinhos, internet, músicas, passam a serem caracterizados temas para materiais didáticos de EA e ganha maior evidencia no momento em que a questão ambiental deixa de ser uma preocupação apenas dos cientistas no final da década de 1990. (DENDENA, 2008, p. 420).

Todavia, no contexto atual, um trabalho de formulação de car-

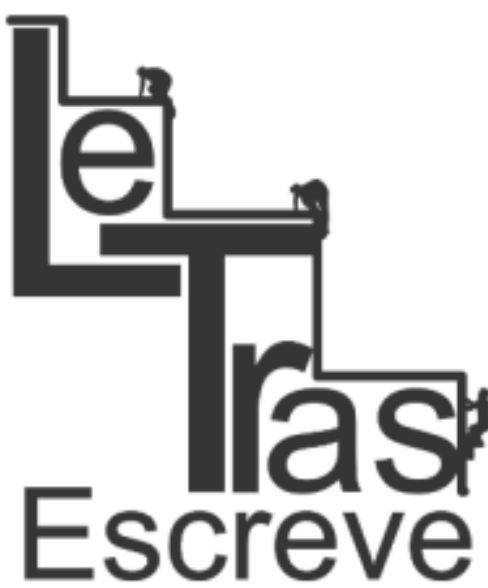

(ISSN 2238-8060) por causa da influência da mídia, das pressões sociais sobre os danos ambientais, dos tratados e acordos políticos, a escola tem se pautado em um currículo de EA e em materiais didáticos - públicos e também privados - que apresentam uma proposta de EA a partir de dois primas: um que tendencia para uma preocupação científica e que fica longe da compressão daqueles que se intitulam como educadores ambientais e um outro no qual se imprime uma mensagem simplista e - podemos até afirmar institucionaliza na escola - uma prática de EA ainda conservacionista, naturalista e que pouco contribui para formação de sujeitos com consciência ambiental, como requerem alguns documentos oficiais .

Dentre os materiais didáticos que ganharam espaço tanto nas mídias impressas quanto digitais, como destacado por Dendena

https://periodicos.unifap.br/index.php/letras

Macapá, v. 7, n. I, Io semestre, 2017. 
(2008), encontram-se as cartilhas quadrinizadas, que utilizam imagens e a quadrinização para apresentar, de forma mais diversificada, lúdica e didática os temas ligados à educação ambiental. Isso tem evidenciado que ao lado do currículo formal escolar, outras iniciativas de educação ambiental estão ganhando espaço, sendo os temas mais recorrentes: a proteção, preservação, conservação, recuperação do meio ambiente, o que tendencia como destacado por Loureiro (2004) para o imbricamento de práticas de educação ambiental.

\section{0 gênero cartilha quadrinizada: um instrumento no trabalho com} educação ambiental

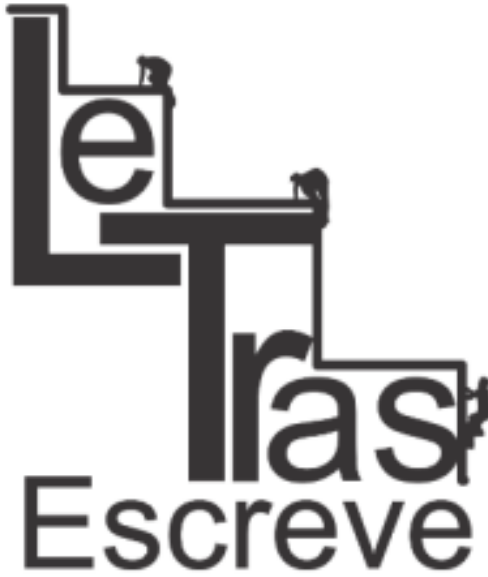

(ISSN 2238-8060)

Para conceituarmos o gênero Cartilha Quadrinhizada (CQ, doravante), recorreremos às discussões de Bakhtin (2003). Em sua teoria sobre gêneros discursivos, Bakhtin destaca que os enunciados gêneros orais e escritos e podemos considerar os multissemióticos $(G O M E S, 2017)^{6}$ - refletem as condição e especificidades das esferas da comunicação 'não só por seu conteúdo (temático) e por seu estilo verbal, ou seja, pela seleção operada nos recursos da língua - recursos lexicais, fraseológicos e gramaticais -, mas também, e, sobretudo, por sua construção composicional (BAKHTIN, 2003, p. 280).

Além disso, o autor destaca ainda que todo discurso é carregado de elos discursivos, ao se referir que

a compreensão de uma fala viva, de um enunciado vivo é sempre acompanhada de uma atitude res-

\footnotetext{
${ }^{6}$ Consideramos, assim como Rojo (2013), Rojo e Barbosa (2015), Grilo e Brait (2013) que os postulados de Bakhtin e do Círculo apresentam como conceitos ou categorias flexíveis que podem ajudar na compreensão tanto da leitura, análise e interpretação das formas de produção de sentido e efeitos de sentido de textos/enunciados de determinados gêneros discursivos cuja marca principal é a constitutiva relação verbo-visual, ou seja, a articulação entre a dimensão ou semioses linguística, oral, escrita e visual, na constituição de textos multissemióticos.
}

https://periodicos.unifap.br/index.php/letras

Macapá, v. 7, n. I, Io semestre, 2017. 


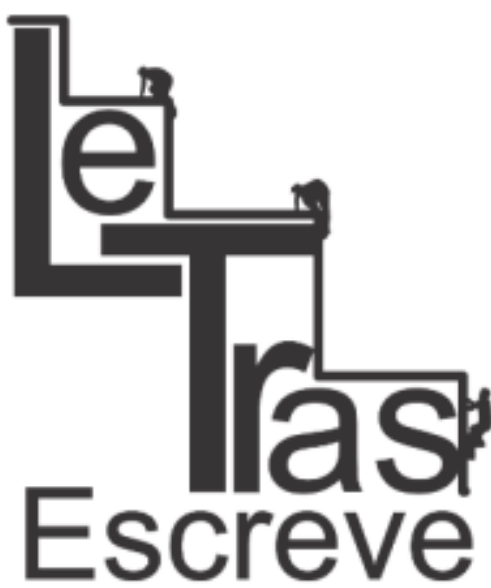

(ISSN 2238-8060)

ponsiva ativa (conquanto o grau dessa atividade seja muito variável); toda compreensão é prenhe de resposta e, de uma forma ou de outra, forçosamente a produz: o ouvinte torna-se o locutor. A compreensão passiva das significações do discurso ouvido é apenas o elemento abstrato de um fato real que é o todo constituído pela compreensão responsiva ativa e que se materializa no ato real da resposta fônica subsequente (BAKHTIN, 2003[1952-3], p. 290).

Ao observarmos o gênero $C Q$ fica evidente que a quadrinização, como componente da estrutura composição desse gênero, ajuda na difusão e propagação dos temas relacionados à educação ambiental. A respeito desse processo, Mendonça (2010) em seus estudos sobre quadrinhos, discute que a quadrinização é a criação de qualquer gênero na linguagem dos quadrinhos, na sua conformação mais moderna, ou a adaptação de um gênero para essa linguagem. Esse tipo de linguagem, de acordo com a autora

\begin{abstract}
poderia ser considerada uma forma de "escrita" que demandaria, do leitor, o domínio de certas estratégias de leitura, como a leitura sequenciada dos quadros, a inferenciação dos quadros "implícitos" nas sarjetas [...] de modo a ser (re)construir o sentido do texto (MENDONÇA, 2010, p. 39).
\end{abstract}

Nessa direção, a CQ caracteriza-se como sendo um gênero multissemiótico, no qual há uma sequência em que a semiose/linguagem verbal e visual se fundem, não havendo como separálas, pois, tal separação comprometeria os efeitos de sentidos pretendidos. Mendonça (2010) mostra-nos ainda que esse gênero é relativamente recente e foi criado no âmbito das campanhas governamentais, com o objetivo de levar, a partir de uma linguagem mais simples, o acesso à informação às pessoas oriundas de contextos socioculturais diversos e com pouca escolaridade, sendo que ele, atualmente,

https://periodicos.unifap.br/index.php/letras

Macapá, v. 7, n. I, Io semestre, 2017. 


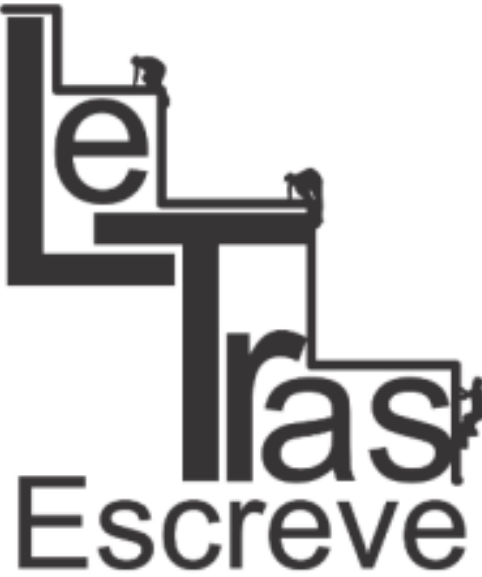

(ISSN 2238-8060)

transita em várias esferas da comunicação e com objetivos diversos, sendo um deles, portanto, a divulgação a popularização de informações.

Gomes e Barros-Mendes (2012) ao falarem sobre esse gênero, no campo da educação ambiental, evidenciam que nas CQ há uma tentativa de aproximação entre os fatos do mundo com o público leigo por meio de estratégias, tais como: a) o uso de imagens e de recursos gráficos que permitam, mesmo ao leitor pouco escolarizado ou com dificuldades de leitura, compreender parte do que é dito no texto; b) a didatização das informações, por meio das frases curtas, do vocabulário de uso comum e das gírias; e c) a junção significativa dos dois itens anteriores: o texto verbal e a imagem, característica inerente à maioria dos quadrinhos.

Portanto, as cartilhas buscaram aproximar-se de um público heterogêneo, de todas as idades, mas com especial atenção às classes desprivilegiadas saberes que the são úteis, mas que antes eram propagados em respeitos muito específicas e com linguagem rebuscada. Esses leitores seriam, no caso brasileiro, a população adulta mais empobrecida, composta, em sua maioria, de pessoas com escolarização precária ou irregular (MENDONÇA, 2010, p. 117).

\section{ANÁLISE DOS DADOS}

Para análise dos dados, situamos este estudo no campo da Linguística Aplicada Interdisciplinar (MOITA-LOPES, 2006), por ser uma área em que há preocupação com questões sociais e por seu interesse está voltado para os usos reais da linguagem. Nesse campo, tem-se adotado metodologias de caráter qualitativo-interpretativista para a observação e análise de dados correspondentes a essas questões que dizem respeito a aspectos socioculturais que os sujeitos fa- 
zem da linguagem. Assim, considerando essa perspectiva de investigação e partir de técnica de pesquisa de análise documental, selecionamos como corpus uma CQ de educação ambiental que faz parte de dados maiores de uma pesquisa envolvida na dissertação de mestrado.

Na no quadro 1, descrevemos a CQ selecionada:

Quadro 1 - CQ 1: 0 meio ambiente está em nossas mãos ${ }^{7}$ INSTITUIÇÕES ENVOLVIDAS NA ELABORAÇÃO DO MATERIAL

Sindicato da Indústria de Extração de Carvão do Estado de Santa Catarina SIECES, Associação Beneficente da Indústria Carbonífera de Santa Catarina SATC, Associação dos Municípios do Extremo Sul Catarinense - AMESC e Associ ação dos Municípios da Região Carbonífera - AMREC.

\begin{tabular}{|c|c|}
\hline TEXTO-ROTEIRO & ARTE E DISNER \\
\hline SATC & SATC \\
\hline AUTORIA E ORGANIZAÇÃO & TEMÁTICA RELACIONADA À EDUCAÇÃO \\
& AMBIENTAL \\
\hline SIECES E SATC & POLUIÇÃO DA ÁGUA, DO SOLO, COLETA \\
SELETIVA, ETC
\end{tabular}

Fonte: Gomes (2013).

Conforme Gomes (2013), esse material é uma publicação pertencente ao Programa de Educação Ambiental de iniciativa do Sindicato da Indústria de Extração de Carvão do Estado de Santa Catarina - SIECESC, sendo que em sua elaboração há somente instituições de (ISSN 2238-8060)

livre iniciativa. A cartilha contém 20 páginas, sendo que a primeira (capa) apresenta distinção colorida e as demais estão na tonalidade apenas preta. A edição em análise da CQ1 destina-se a alunos da 3ạ série/4ㅇ ano do ensino fundamental e faz parte de uma coletânea ampliada e republicada em 2009.

Vale destacar, também, que diferentemente de outros materiais de educação ambiental, essa cartilha não explora um único tema relacionado à educação ambiental, mas sim vários, desde reflexões sobre poluição da água até poluição sonora e radioativa. Além disso,

\footnotetext{
7 Disponível em http://www.siecesc.com.br/pdf/cartilha_do_meio_ambiente_4_ano.pdf. Acesso em 16 abr. 2016.
}

https://periodicos.unifap.br/index.php/letras

Macapá, v. 7, n. I, Io semestre, 2017. 
o material apresenta, em uma linguagem mais técnica, uma versão para o professor, configurando-se mais como uma cartilha de divulgação cientifica nesse caso.

\subsection{Transpondo e didatizando: o que nos revela a CQ de educação ambiental?}

Feita a apresentação do corpus, passamos, agora, para a análise dos processos de transposição didática e didatização propostos a partir do material. Para a análise, buscamos principalmente as atividades que em a CQ oferece, durante ou após explicações sobre as temáticas relacionadas com educação ambiental, atividades tanto de leitura e interpretação quanto atividades práticas. Para iniciar a análise, apresentamos, abaixo, dois recortes de excertos de informações e as atividades das CQ 1:

Figura 3: Exemplo de atividade e atividade presente na CQ

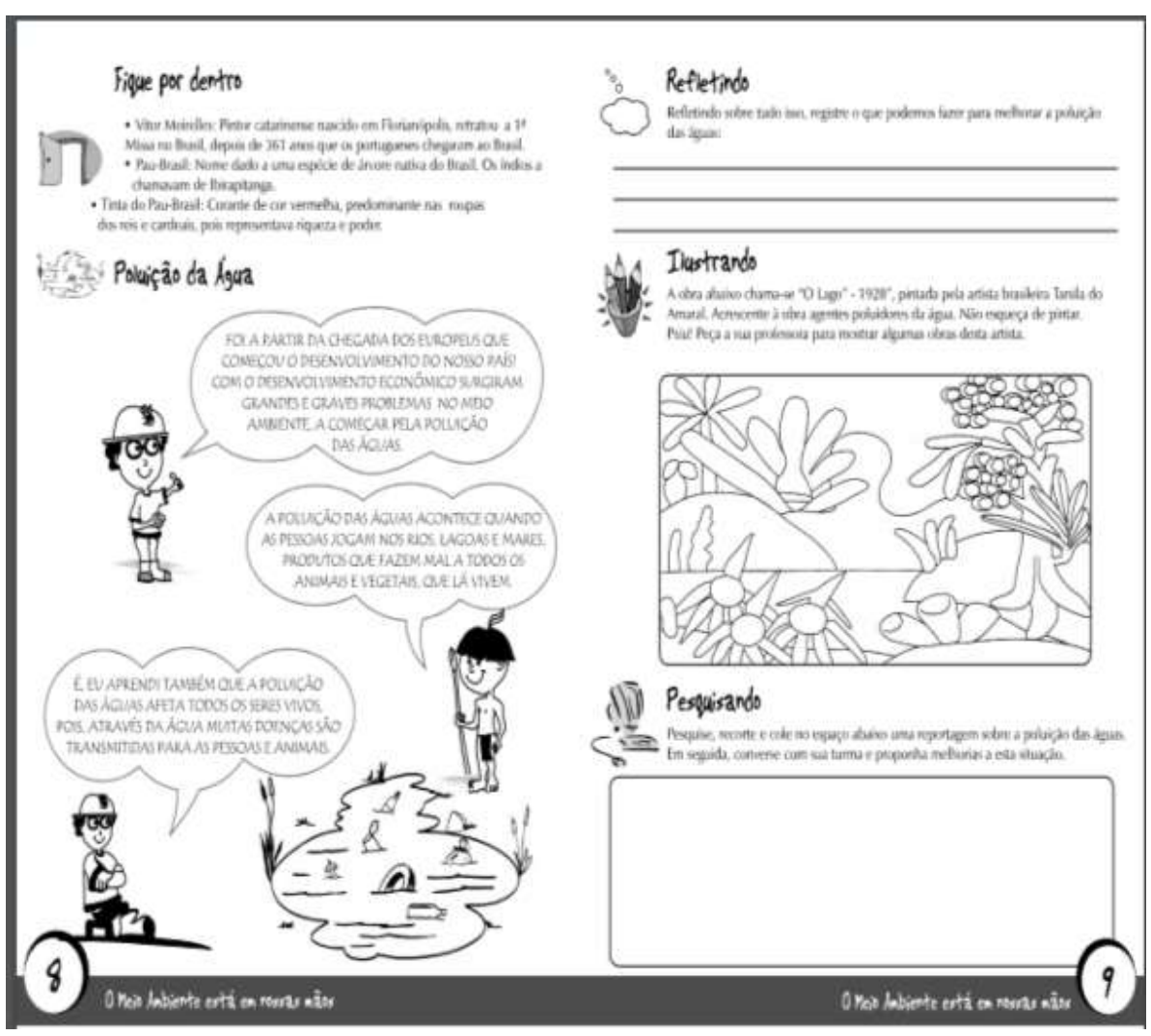

Fonte: CQ 1 (2009).

https://periodicos.unifap.br/index.php/letras

Macapá, v. 7, n. I, Io semestre, 2017. 
Figura 4: Exemplo de atividade e atividade presente na CQ

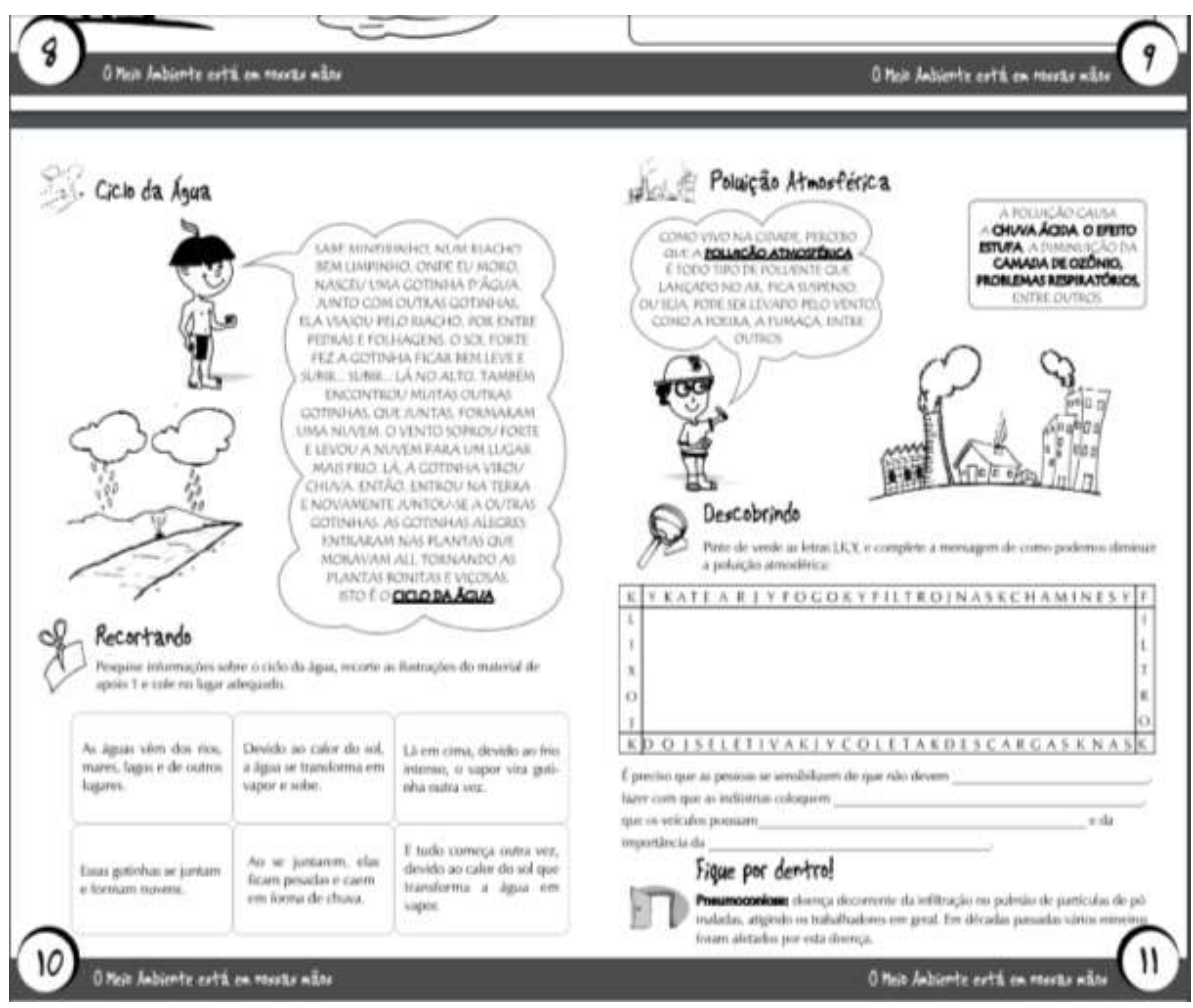

Fonte: CQ 1 (2009).

Como mencionado anteriormente, os saberes precisam ser alterados, reformulados, ou seja, didatizados para entrarem sem sala de aula, e não apenas resumidos e adaptados de forma simples. Considerando-se tal proposição, nas atividades da CQ em questão, é possível perceber que, primeiramente, os autores do material apresentam algumas explicações sobre problemáticas ambientais mais atuais (poluição da água, poluição atmosférica) e, paralelamente, tratam de temas ambientais, como por exemplo, o ciclo da água. Para essa apresentação dos problemas e temas ambientais, os autores utilizamse de modalizações discursivas para aproximar esses temas dos alunos e, para essa conceituação, também, trata-os a partir de uma perspectiva interdisciplinar, pois nas atividades das páginas 8 e 9, são apresentados aos alunos conceitos a partir da área de artes e história.

Além desse viés didático, como se trata de um gênero quadri-

https://periodicos.unifap.br/index.php/letras

Macapá, v. 7, n. I, Io semestre, 2017. 


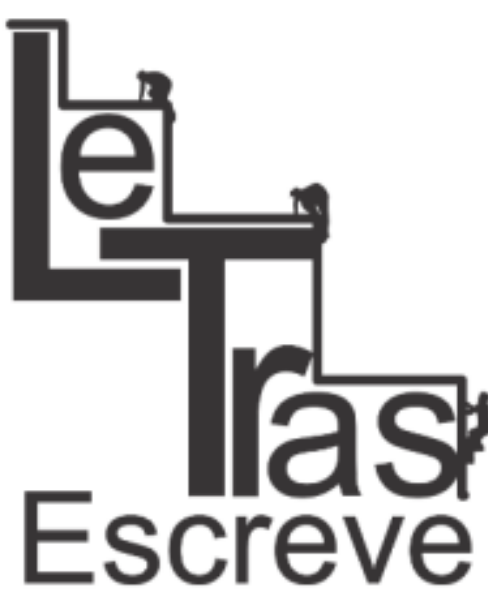

(ISSN 2238-8060)

nizado, são utilizadas imagens que, unidas com a linguagem verbal, ajudam na construção de efeitos de sentidos pretendidos (LEKME, 2010 [1998]), que no caso da primeira atividade dizem respeito à conscientização da poluição da água. Tal modalização, na organização do material, retorna literalmente ao modelo canônico de transmissão de conhecimento como aquele praticado pela escola, porém o que chama atenção é que não se propõe, nas atividades, meramente a retirada de definições das problemáticas ambientais, nem tampouco a retomada aos preceitos científicos que explicam essas questões, ao contrário, busca-se com a atividade a dessincretização desse saber de referência (CHEVALLARD, 1985), pois, uma função do saber a ensinar é fazer com que o saber perca qualquer ligação com o ambiente epistemológico no qual foi criado para, a partir daí, torna-se um objeto de ensino, sendo que por meio desse processo de dessincretização o saber é reconstituído em um novo contexto epistemológico, com a função agora, como propõe Chevallard (1985) de propósitos didáticos, ou seja, de um saber de ensino.

Pelos excertos vemos, também, que se instiga o aluno a realizar a sobreposição de uma imagem sobre a outra, como se observa na atividade llustrando, da página 9:

Figura 5 - Recorte de atividade da CQ

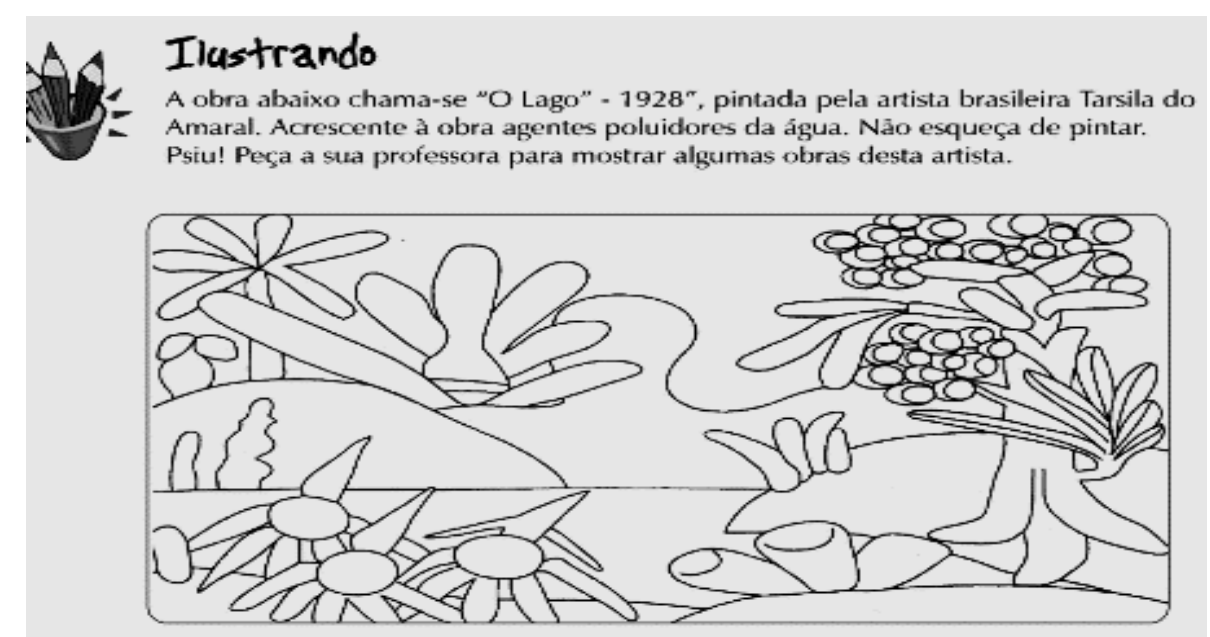

Fonte: CQ 1 (2009).

https://periodicos.unifap.br/index.php/letras

Macapá, v. 7, n. I, Io semestre, 2017. 


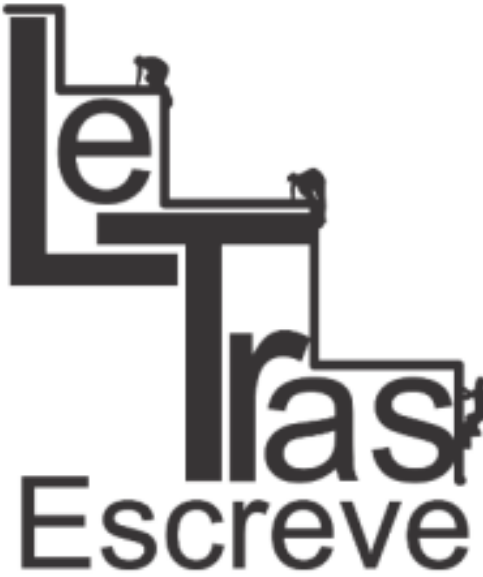

(ISSN 2238-8060)

A atividade objetiva levar o aluno a perceber que a inserção dos itens "agentes poluidores da água", ao serem inseridos no quadro, quebram a harmonia existente, e deixam, dessa forma, a paisagem antes vista como bela, agora, desagradável aos olhos do leitor. Nesse caso, vemos simplificação do tema sobre poluição da água e também do macro temática que é a educação ambiental. Podemos inferir que essa fragilidade na sistematização do saber de referência sobre poluição ambiental ocorre por falta de preparação daqueles que criaram o roteiro do gênero e da equipe que elaborou a cartilha, uma vez vemos pouca consistência no tratamento didático dos temas relacionados à educação ambiental

Assim, ao contrário do saber de referência que depois de ser legitimado pela comunidade científica se torna parte da cultura da humanidade, o saber a ensinar e seus objetivos podem não sobreviver até o final do processo da TD e da didatização, podendo tornarem-se obsoletos no contexto escolar ou banalizados no contexto sociocultural, sofrendo pressões de grupos provenientes da noosfera, fazendo com que sejam descartados, como se pode observar nas atividades das duas $C Q$, onde destacam-se algumas questões que simplificam em função do público alvo, no caso crianças que aos pouco estão tendo conscientização sobre questões ambientais.

Contudo, essas ações buscam um único objetivo, melhorar o ensino com o aumento da aprendizagem, mas pelo fato de muitos ainda não compreenderem os processos de TD e de didatização no trabalho com a educação ambiental formal, acabam acreditando que esse campo educacional está relacionado como uma forma simplificada de ensino e sem sistematização de forma mais clara sobre os temas relacionados com a educação ambiental. 


\section{CONSIDERAÇÕES FINAIS}

A cartilha que serviu de corpus para análise neste artigo, voltada para temáticas de educação ambiental, revela-se como um gênero situado na interface, como propõe Bakhtin (2003[1952/3]) de esferas de comunicação institucionais e a escolar. E apesar de apresentar um caráter didático na apresentação das informações ao público-alvo, procura envolver os leitores a que se dirigem - crianças tanto para leitura do material em viés mais lúdico e didático (apesar de não apresentar cores atraentes) quanto para a adesão de mostrar, os problemas ambientais, de forma menos científica.

Quanto aos processos de transposição didática e didatização,

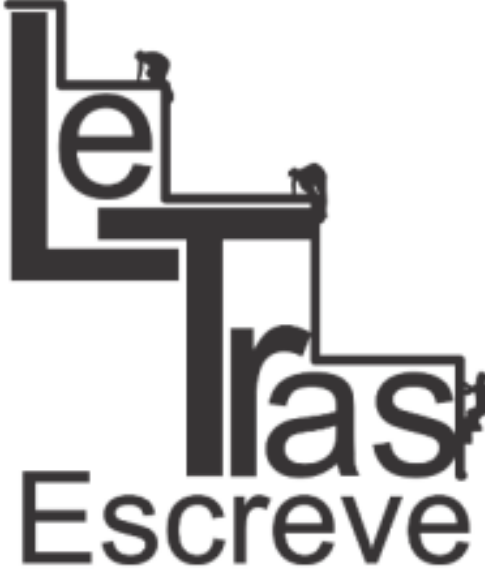

(ISSN 2238-8060) fica evidente que esses processos podem sim serem concretizados a partir de temas ambientais, uma vez que nas duas atividades em análise, apesar de trabalharem de forma simples, conduzem o leitor - no caso em potencial a criança - no processo de transposição e didatização dos temas ambientais não apenas para reprodução de conhecimentos epistemológicos sobre problemas ambientais, mas favorecem acima de tudo reflexões maiores a respeitos deles, levando os alunos a uma visão mais holística e crítica sobre a educação ambiental.

\section{REFERÊNCIAS}

BAKHTIN, M. Os gêneros do discurso (1952-1953). In.: Estética da criação verbal. Trad. Maria Ermantina Galvão Gomes e Pereira. São Paulo: Martins Fontes, 2003. p. 277-326.

BARROS-MENDES, A.N.N. Os gêneros orais formais e públicos: algumas reflexões. 2005. 201f. Tese (Doutorado em Linguística Aplicada e Estudos da linguagem). Pontifícia Universidade Católica de São Paulo- 


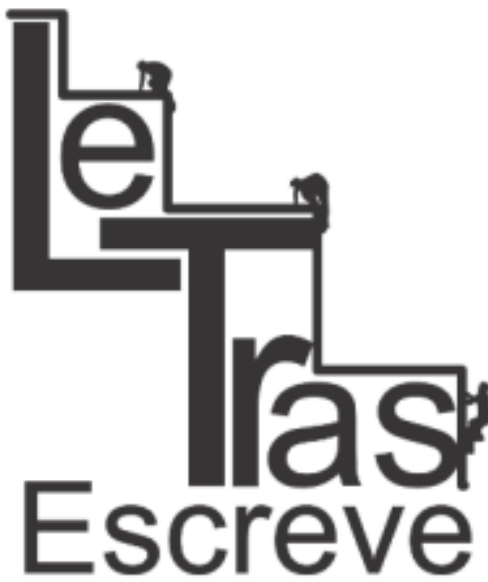

(ISSN 2238-8060)

PUCC/SPUNIGE/SUISSE: São Paulo, 2005.

BEZERRA, M. A. Da redação ao gênero textual: a didatização da escrita na sala de aula. In: MOURA, D. (org) Os desafios da língua: pesquisas em língua falada e escrita. Maceió: EDUFAL, 2008, p. 135-138.

BUNZEN, C. Os significados do letramento escolar como uma prática sociocultural. In: VÓVIO, C; SITO, L; DE GRANDE, P. Letramentos: rupturas, deslocamentos e repercussões de pesquisa em Linguística aplicada: Campinas, SP: Mercado de Letras, p. 99-120, 2010.

Carvalho, I. C. M. A invenção do sujeito ecológico: identidades e subjetividade na formação dos educadores ambientais. In: Sato, M. \& carvalho, I. C. M. (orgs) Educação Ambiental; pesquisa e desafios. Porto Alegre: Artmed, 2005.

CARVALHO, I. C. M. Educação ambiental: a formação do sujeito ecológico. 2.ed. são Paulo: Cortez, 2004.

CHEVALLARD, Yves. La transposition didactique: du savoir savant au savoir enseigné. Paris: La Pensée Sauvage, 1985.

GOMES, R; BARROS-MENDES, A.N.N. Educação ambiental à luz da análise dialógica do discurso: saber científico e quadrinização no gênero textual cartilha quadrinizada. Estação Científica (Macapá), v. 2, p. 65-78, 2014.

GUIMARÃES, M. A formação de educadores ambientais. Campinas SP: Papirus, 2004a.

KLEIMAN, A. Trajetórias de acesso ao mundo da escrita: relevância das práticas não escolares de letramento para o letramento escolar. Revista Perspectiva, UFSC. Florianópolis, Santa Catarian, v. 28, n. 1, 2010.

LOUREIRO, C. F. B. Trajetórias e fundamentos da educação ambiental. São Paulo: Cortez, 2004.

MARTINAND, J. L. Connaître et Transformer la Matière. Peter Lang,

https://periodicos.unifap.br/index.php/letras

Macapá, v. 7, n. I, Io semestre, 2017. 
Berna, 1986.

MENDONÇA, Márcia. Ciência em quadrinhos: imagem e texto em cartilhas educativas. Recife: Bagaço, 2010.

MOITA LOPES, L. P. da. Linguística aplicada e vida contemporânea: problematização dos construtos que têm orientado a pesquisa. In: Por uma linguística aplicada INdisciplinar. São Paulo: Parábola Editorial, 2006.

PINHO ALVES, José. A Eletrostática como exemplo de Transposição Didática. In: PIETROCOLA, Maurício (org). Ensino de física: conteúdo, metodologia e epistemologia numa concepção integradora. Florianópolis: Editora da UFSC, 2001. p. 77-100.

REIGOTA, M. A floresta e a escola: Por uma educação ambiental pósmoderna. São Paulo: Cortez, 2004.

ROJO, R. H. R. Letramento e capacidades de leitura para a cidadania. São Paulo: SEE: CENP, 2004. Texto apresentado em Congresso realizado em maio de 2004.

SATO, M.; CARVALHO, Isabel. Educação Ambiental: Pesquisa e desafios. São Paulo: Artmed, 2005.

TARDIF, Maurice. Saberes docentes e formação profissional. 4a Ed.

Rio de Janeiro: Vozes, 2004.

Recebido em 07/02/2017

Aceito em 20/03/2017 